\title{
CARDIOVASCULAR DRUG LABELING: DO THEY HAVE INFORMATION ON NECESSARY PRECAUTIONS FOR OLDER PEOPLE?
} Bulas de medicamentos cardiovasculares: elas têm
informações sobre precauções necessárias aos idosos?

\author{
Lucas Oliveira Marques ${ }^{\circledR} \oplus$, Roberta Coutinho Vasconcelos ${ }^{\circledR} \bullet$, André Oliveira Baldonib $\bullet$, \\ Ana Cristina Nogueira Rodrigues Pestana ${ }^{\circledR} \odot$, Farah Maria Drumond Chequer ${ }^{\natural} \bullet$
}

OBJECTIVE: To analyze the existence of information on drug labeling intended for health professionals on the precaution of cardiovascular drugs use in older people. METHODS: This is a documentary study, carried out with the analysis of data contained in drug labelings. The existence of information on precautions in the use of drugs for older people as described in the 2016 Brazilian Consensus on Potentially Inappropriate Drugs for Older People (Consenso Brasileiro de Medicamentos Potencialmente Inapropriados para Idosos de 2016). RESULTS: Of the 29 drugs belonging to the cardiovascular system group that should be avoided by older people and are available in Brazil, 15 are independent of the clinical condition. Of these fifteen, only three drugs (20\%) have explicit information in accordance with the Consensus (methyldopa, digoxin, and spironolactone); two (13.33\%) have missing explicit information; four (26.66\%) have explicitly discordant information; and six drug labels (40\%) were categorized as non-explicit information. Regarding drug precautions according to clinical condition, 14 drugs were included. Of these, 12 (85.71\%) have equal contraindications of that of Consensus on their drug labels, however, non-explicit; and two (14.28\%) contraindications are missing. CONCLUSION: Most drug labels lack information on the precautions for the use of drugs in older people.

KEYWORDS: older people; potentially inappropriate drug list; drug prescriptions; drug labeling.

OBJETIVO: Analisar a existência de informações, em bulas destinadas aos profissionais de saúde, sobre precaução de uso de medicamentos cardiovasculares em idosos. METODOLOGIA: Trata-se de estudo documental realizado por meio de análise de dados contidos em bulas de medicamentos. Analisou-se a existência, na bula, de informações sobre precauções no uso de medicamentos para idosos, conforme descrito no Consenso Brasileiro de Medicamentos Potencialmente Inapropriados para Idosos de 2016. RESULTADOS: Dos 29 medicamentos pertencentes ao grupo do sistema cardiovascular que devem ser evitados por idosos e estão disponíveis no Brasil, 15 independem da condição clínica prévia do paciente para que sejam vetados para os idosos. Desses 15 , apenas 3 medicamentos (20\%) têm informações explícitas concordantes com o Consenso (metildopa, digoxina e espironolactona); 2 (13,33\%) têm informações explícitas ausentes; 4 (26,66\%) têm informações explícitas discordantes; e 6 bulas (40\%) foram categorizadas como informações não explícitas. Quanto às precauções dos medicamentos de acordo com a condição clínica do paciente, incluíram-se 14 medicamentos que devem ser evitados por idosos e estão disponíveis no Brasil. Destes, 12 (85,71\%) têm em suas bulas recomendações concordantes com o Consenso, porém não explícitas, e 2 (14,28\%) não têm as contraindicações. CONCLUSÕES: A maioria das bulas carece de informações sobre precauções de uso de medicamentos para a população idosa. PALAVRAS-CHAVE: idosos; medicamentos potencialmente inapropriados; prescrições medicamentosas; bula de medicamentos.

anniversidade de Itaúna - Itaúna (MG), Brazil.

bUniversidade Federal de São João del-Rei - Divinópolis (MG), Brazil.

Correspondence data

Farah Maria Drumond Chequer - Laboratório de Análises Toxicológicas, Universidade Federal de São João del-Rei, Campus Centro-Oeste Dona Lindu Rua Sebastião Gonçalves Coelho, 400 - Chanadour - CEP: 35501296 - Divinópolis (MG), Brasil. E-mail: farahchequer@ufsj.edu.br Received on: 05/05/2020. Accepted on: 07/18/2020

https://doi.org/10.5327/22447-212320202000054 


\section{INTRODUCTION}

The demographic growth of the older population in recent years is evident, a fact explained by the improvement in living conditions, and also by scientific and technological improvement. ${ }^{1}$ At the same time, there is the growing phenomenon of multimorbidity, which leads this population to great demand for health services and a high drug consumption. ${ }^{2}$ Literature shows that the rate of drug use by older people is approximately $80 \%$, thus representing the main consumers of these therapeutic inputs worldwide. ${ }^{3}$ In agreement with these facts, information from the National Survey on Access, Use and Promotion of Rational Use of Medicines in Brazil (Pesquisa Nacional sobre Acesso, Utilização e Promoção do Uso Racional de Medicamentos no Brasil - PNAUM) shows that $93 \%$ of older Brazilians chronically use at least one drug, and $18 \%$ use polypharmacy. ${ }^{4}$

Also important is the fact that older people have physiological changes related to age, such as reduced liver and kidney functions, and changes in body composition, which affect the pharmacokinetics and pharmacodynamics of drugs. ${ }^{5}$ Therefore, there was a need to create lists of explicit criteria for use precaution of potentially inappropriate drugs (PIM), in order to mitigate the risks of prescribing these drugs, such as the 2019 Beers Criteria $^{6}$ and the Brazilian Consensus on Potentially Inappropriate Medicines for Older People (Consenso Brasileiro de Medicamentos Potencialmente Inapropriados para Idosos - CBMPII), which contribute with the quality and safety of prescriptions for this population. ${ }^{7}$

The use of PIM by older people is a research topic in Brazil and in the world because the promotion of health and care to this population proves to be increasingly needed. ${ }^{8}$ Thus, the rational drug use by older people is of fundamental importance to avoid adverse events that may harm the health and quality of life of this population, who is growing at a rapid pace.,

In the context of PIM use, Brazilian studies show that drugs that act on the cardiovascular system are involved in 40 to $56 \%$ of all medical prescriptions for older people. ${ }^{9,10}$ Given this, critically analyzing the precautions contained in drug labels is essential to generate evidence on the need for possible changes in regulatory agencies, pharmaceutical industries, and clinical practice.

The objective is to analyze the existence of information on precaution for the use of cardiovascular drugs in older people contained on drug labels for health professionals.

\section{METHODS}

The present paper consists of a documentary study, in which data contained in the electronic drug labels made available by the Brazilian Health Surveillance Agency (Agência Nacional de Vigilância Sanitária - ANVISA), on the website: http://www.anvisa.gov.br/datavisa/fila_bula/index.

Information from the CBMPII was the reference used as a standard of comparison with the information on the drug label. The analysis considered drugs that should be avoided independently or depending on the older person's previous clinical condition. In CBMPII, there is information warning about the use of these drugs in this population. Information is based on effectiveness, adversities, and precautions and/or contraindications. ${ }^{7}$

Drugs related to the cardiovascular system, present in the CBMPII, were identified, and their availability in Brazil was reviewed and consulted on the ANVISA website (https://consultas.anvisa.gov.br/\#/medicamentos/).Thereby, drug labels whose registration status was "expired/canceled" were not included in analysis.

Drugs were divided into two groups: those that contain precautions regardless of the person's clinical condition and those that depend on the person's clinical condition. Then, the respective instructions for professionals were sought. If more than one drug labeling and/or drug labels from different laboratories were found, the most recent publication was considered.

After selecting the drug labels for cardiovascular system medications available in Brazil that are independent of the person's clinical condition, the presence or absence of explicit information on precautions for use for older people was first identified, considering an individual aged 65 years or older as an older person. After identifying information, it was categorized into: "explicit information" and "non-explicit information". "Explicit" were those in which the drug labeling provided information on precautions, in the title and/or in the body of the text, containing the descriptors "older people", "special population", and/ or "65 years old". "Non-explicit" information was when drug labels did not have this specification.

Then, explicit information on drug labels was compared to the descriptions contained in CBMPII, ${ }^{7}$ and whether such information was concordant, discrepant, or missing was analyzed.

Concordant information was considered when drug labels contained information similar to the justification provided by the CBMPII when determining that the drug should be avoided in older adults; discrepant, if the information on drug labels was opposed to the CBMPII; and missing information, if the reason described by the CBMPII was not mentioned on the drug label. It was considered as "non-explicit information" when the drug 
label did not have a specific section for the population studied, regardless of whether its content agreed, discordant, or missing from the CBMPII. Thus, after the critical comparison between the information contained in drug labels and that of the CBMPII, information was categorized into:

- concordant explicit information;

- conflicting explicit information;

- missing explicit information;

- non-explicit information.

The synthesis of the data collection process is described in Figure 1.
As for the drugs that should be avoided in older people according to their clinical condition, it was analyzed, first, whether the justification for avoiding the use mentioned by CBMPII was present in drug labels. If so, whether such information was specified for the older population or not as then observed. Thus, information was categorized as "explicit", "non-explicit", and "missing".

For comparing information on the precautions for older people available on drug labels and in the CBMPII, ${ }^{7}$ documentary analysis of each drug labeling was carried out by two researchers independently. To analyze and interpret the data, a database in the form of spreadsheets was built using Microsoft Office Excel 2016.

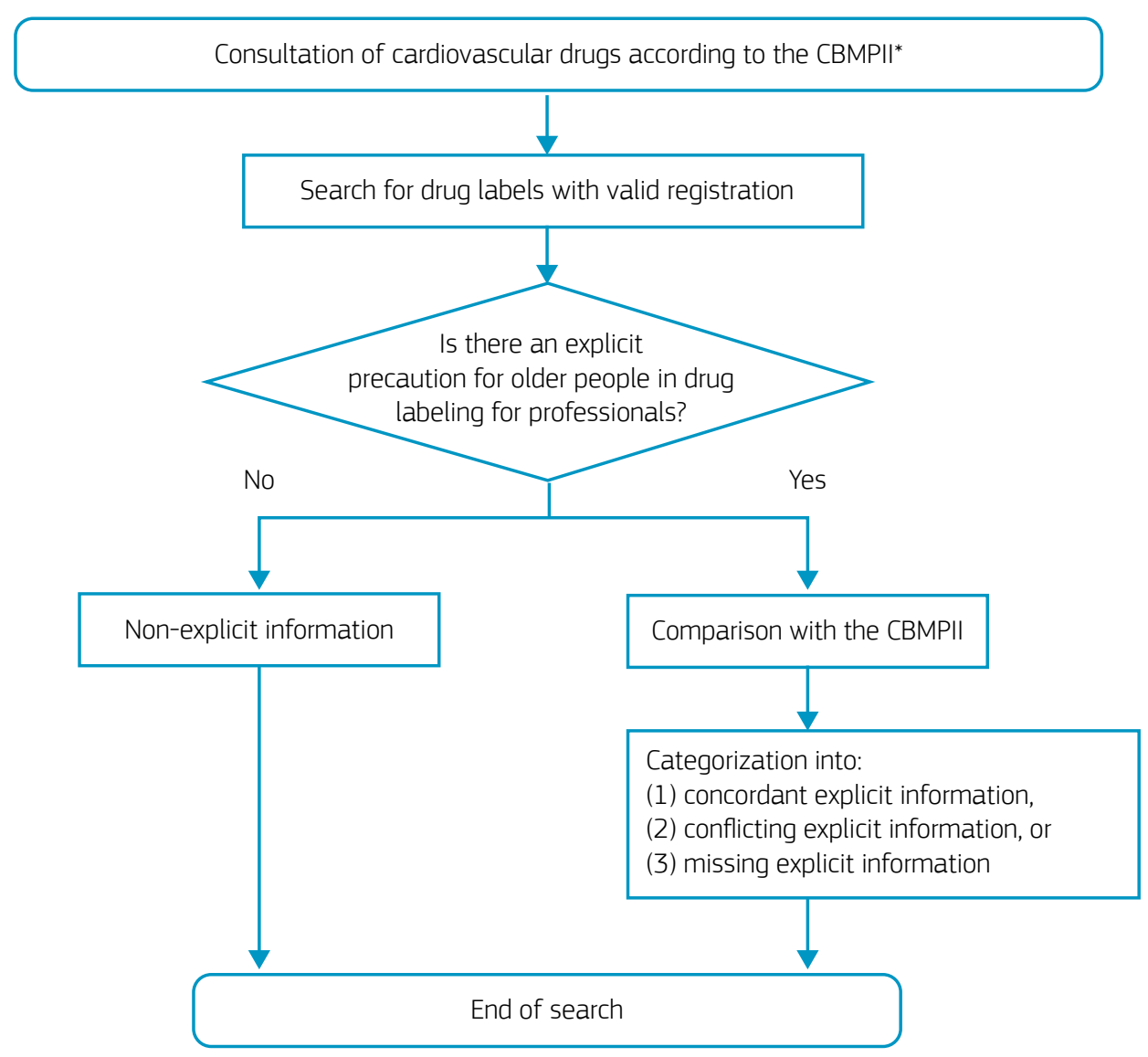

*CBMPII: Brazilian Consensus on Potentially Inappropriate Medicines for Older People (Consenso Brasileiro de Medicamentos Potencialmente Inapropriados para Idosos).

Figure 1 Flowchart of the data collection process. 


\section{RESULTS}

Of the 23 drugs belonging to the cardiovascular system group that should be avoided by older people, regardless of the person's clinical situation, listed by CBMPII, eight of them have no active registration with ANVISA. Therefore, 15 drug labels for professionals were analyzed (Chart 1). There are duplicate drugs, but they were analyzed separately, given that the context in which they are inserted in the CBMPII is different. ${ }^{7}$

Information contained in $40 \%$ of drug labels $(n=6)$ was categorized as non-explicit information, $13.33 \%(\mathrm{n}=2)$ as missing explicit information, $26.66 \%(\mathrm{n}=4)$ as conflicting explicit information, and $20 \%(\mathrm{n}=3)$ as concordant explicit information.

As for the drugs listed by the CBMPII that should be avoided in certain clinical conditions and that act on the cardiovascular system, 14 were selected, because of the 18 drugs listed by the CBMPII, one is not marketed in Brazil, and three have no active registration for use as vasodilators.

Considering that there are duplicate drugs, $85.71 \%$ of information on drug labels $(n=12)$ were categorized as non-explicit, and $14.28 \%(\mathrm{n}=2)$ as missing (Chart 2$)$.

Chart 1 Comparison between the contents of the drug label and the description of the precautions for use contained in the Brazilian Consensus on Potentially Inappropriate Medicines for Older People for cardiovascular drugs.

\begin{tabular}{|c|c|c|c|}
\hline $\begin{array}{l}\text { Drugs contained } \\
\text { in the CBMPII }\end{array}$ & $\begin{array}{l}\text { Justification according } \\
\text { to the CBMPII }\end{array}$ & $\begin{array}{l}\text { Content of the } \\
\text { explicit information }\end{array}$ & $\begin{array}{l}\text { Comparative analysis } \\
\text { between information } \\
\text { on the drug label and } \\
\text { that of the CBMPII }\end{array}$ \\
\hline Doxazosin & $\begin{array}{l}\text { Use associated to a high risk } \\
\text { of orthostatic hypotension. } \\
\text { Not recommended for routine } \\
\text { treatment of hypertension. } \\
\text { There are alternatives with } \\
\text { better risk-benefit ratio }\end{array}$ & $\begin{array}{l}\text { It states that there are no } \\
\text { specific recommendations } \\
\text { for older people }\end{array}$ & Missing explicit information \\
\hline Clonidine & \multirow{2}{*}{$\begin{array}{l}\text { High risk of adverse effects } \\
\text { to the Central Nervous } \\
\text { System (CNS). It may } \\
\text { cause bradycardia and } \\
\text { orthostatic hypotension }\end{array}$} & $\begin{array}{l}\text { In the section on adversities } \\
\text { and precautions, it does not } \\
\text { quote the descriptors to be } \\
\text { considered explicit information }\end{array}$ & Non-explicit information \\
\hline Methyldopa & & Occurrence of syncope & $\begin{array}{l}\text { Concordant explicit } \\
\text { information }\end{array}$ \\
\hline Amiodarone & \multirow{3}{*}{$\begin{array}{l}\text { Data suggest that heart rate } \\
\text { control provides a better } \\
\text { risk-benefit profile than } \\
\text { rhythm control in older } \\
\text { people. Amiodarone is } \\
\text { associated to thyroid } \\
\text { disease, lung disorders } \\
\text { and prolongation of } \\
\text { the QT interval }\end{array}$} & $\begin{array}{l}\text { More pronounced } \\
\text { reduction in heart rate }\end{array}$ & Missing explicit information \\
\hline Propofenone & & $\begin{array}{c}\text { No differences were observed } \\
\text { in the safety or efficacy } \\
\text { of the drug when used } \\
\text { by older people }\end{array}$ & $\begin{array}{l}\text { Conflicting explicit } \\
\text { information }\end{array}$ \\
\hline Sotalol & & $\begin{array}{l}\text { Beta-adrenergic blocking } \\
\text { agents have been used safely } \\
\text { and effectively in older people }\end{array}$ & $\begin{array}{l}\text { Conflicting explicit } \\
\text { information }\end{array}$ \\
\hline $\begin{array}{l}\text { Acetylsalicylic acid } \\
\text { dose }>150 \mathrm{mg} / \text { day }\end{array}$ & $\begin{array}{l}\text { Increased risk of } \\
\text { gastrointestinal bleeding, } \\
\text { with no evidence of } \\
\text { increased efficacy }\end{array}$ & $\begin{array}{l}\text { In the side effects and } \\
\text { precautions section, it does } \\
\text { not quote the descriptors to be } \\
\text { considered explicit information }\end{array}$ & Non-explicit information \\
\hline $\begin{array}{l}\text { Acetylsalicylic acid } \\
\text { to treat dizziness not } \\
\text { clearly attributable to } \\
\text { cerebrovascular disease. }\end{array}$ & $\begin{array}{l}\text { Increased risk of } \\
\text { gastrointestinal bleeding, } \\
\text { with no evidence of } \\
\text { increased efficacy }\end{array}$ & $\begin{array}{l}\text { In the side effects and } \\
\text { precautions section, it does } \\
\text { not quote the descriptors } \\
\text { to be considered explicit } \\
\text { information }\end{array}$ & Non-explicit information \\
\hline
\end{tabular}

CBMPII: Brazilian Consensus on Potentially Inappropriate Medicines for Older People (Consenso Brasileiro de Medicamentos Potencialmente Inapropriados para Idosos). 
Chart 2 Comparison between drug labels for drugs that act on the cardiovascular system and the description of precautions for use contained in the Brazilian Consensus on Potentially Inappropriate Medicines for Older People (CBMPII) dependent on clinical condition.

\begin{tabular}{|c|c|c|}
\hline $\begin{array}{l}\text { Drugs contained } \\
\text { in the CBMPII }\end{array}$ & $\begin{array}{l}\text { Justification according } \\
\text { to the CBMPII }\end{array}$ & $\begin{array}{l}\text { Comparative analysis between information } \\
\text { on the drug labeling and that of the CBMPII }\end{array}$ \\
\hline Acetylsalicylic acid & \multirow{4}{*}{$\begin{array}{l}\text { High risk of bleeding in patients with } \\
\text { concomitant hemorrhagic disorder }\end{array}$} & Non-explicit contraindication \\
\hline Clopidogrel & & Non-explicit contraindication \\
\hline Dipyridamole & & Missing contraindication \\
\hline Warfarin & & Non-explicit contraindication \\
\hline Diltiazem & \multirow{2}{*}{ Possible worsening of constipation } & Non-explicit contraindication \\
\hline Verapamil & & Non-explicit contraindication \\
\hline Carvedilol & \multirow{2}{*}{ Increased risk of bronchospasm } & Non-explicit contraindication \\
\hline Propranolol & & Non-explicit contraindication \\
\hline Hydrochlorothiazide & \multirow{2}{*}{ Possibility of aggravating gout } & Non-explicit contraindication \\
\hline Chlortalidone & & Non-explicit contraindication \\
\hline Diltiazem & \multirow{2}{*}{$\begin{array}{l}\text { Potential to promote fluid retention } \\
\text { and aggravation }\end{array}$} & Non-explicit contraindication \\
\hline Verapamil & & Non-explicit contraindication \\
\hline Cilostazol & $\begin{array}{l}\text { Potential to promote fluid retention } \\
\text { and exacerbate heart failure }\end{array}$ & Non-explicit contraindication \\
\hline Hydralazine & Risk of syncope, falls & Missing contraindication \\
\hline
\end{tabular}

\section{DISCUSSION}

When analyzing information on drug labels and CBMPII critically, there are significant gaps in the contents of the Brazilian drug labels with regard to the precautions for use in older people, given only three of the cardiovascular system medications have concordant explicit information.

Four drugs - propafenone, sotalol, and furosemide (the latter being presented twice by the CBMPII) - have explicit information that differs from that of CBMPII. Interestingly, the content of such information concerns drug effectiveness, considering that the CBMPII warns about the existence of better options on the market in terms of results of using these drugs. ${ }^{7}$ Observing this conflict, ANVISA should encourage the publication of clinical results of drugs efficacy so that, even if there are differences between studies and drug labels, the prescribers, in case of doubt or lack of better options in the environment in which the person is inserted, have greater scientific basis for decision making. This already occurs at the European Medicines Agency, which obliges manufacturers to make the protocols and results of safety studies public. ${ }^{11}$

Two drugs (amiodarone and doxazosin) have missing explicit information, once the justification reported by the
CBMPII was not found in the selected sections of these drug labels. Amiodarone is considered at risk, according to the CBMPII, because it is associated to thyroid disease, lung disorders, and prolongation of the QT interval. This is one of the main drugs associated to adverse events. When the clinical condition of older people requires its use and it cannot be replaced, strict monitoring of the cardiovascular system and possible adverse effects should be performed.,12

Finally, six drug labels analyzed do not have any specific precautions for older people. The drugs in these drug labels are clonidine, dipyridamole, ticlopidine, nifedipine, and acetylsalicylic acid (this is found in two different contexts in the CBMPII). Acetylsalicylic acid increases the risk of severe bleeding, especially intestinal bleeding in older people., ${ }^{73}$ Besides that, the daily use of this drug tends to be higher in older people due to the higher incidence and greater risk of heart disease in this age group. ${ }^{14,15}$ Therefore, their prescription should be made with caution and consider its risks and benefits.

When paying attention to the fact that drugs that act on the cardiovascular system are potential risk factors for adverse events, the results of this study are worrying, given that older 
people use these drugs with high frequency. The adverse impact on quality of life and costs are also significant, because they increase the chances of health problems, such as admissions to emergencies, hospitalizations, or even death. ${ }^{12,16}$ In addition, the minority of drug labels of the studied drugs have explicit content for older people and are in accordance with the clinical warnings provided by the CBMPII. ${ }^{7}$

Drug labels aim to make information clear in order to contribute to the rational and safe use of drugs. ${ }^{17}$ Despite technical limitations, drug labels are ways of disseminating and consulting information for both professionals and users. ${ }^{18,19}$ Therefore, it is of utmost importance that drug labels are written in a complete manner, so that the prescribing physician, the clinical pharmacist, the user and even the pharmaceutical industry have quality information, updated and in line with the epidemiological profile of Brazil. ${ }^{17}$

In this context, ANVISA published a Collegiate Board Resolution (Resolução de Diretoria Colegiada - RDC) No. 47 of 2009 to standardize and assist in the preparation of quality information on drug labels in Brazil. This resolution recommends that all drugs must have specific instructions for users and professionals, which must be contained in the Electronic Drug Labels of ANVISA. Such drug labels must contain contraindications, warnings, and precautions, when applicable, for special populations - for example, older people. ${ }^{20}$

All the drug labels analyzed have a publication date later than 2016, that is, after the publication of the CBMPII and RDC No. 47 of $2009 .{ }^{7,20}$ However, the present study demonstrated that, even with the existence of standardization standards that aim at improving information on drugs and with the publication of the CBMPII, ${ }^{7}$ drug labels that work on the cardiovascular system studied lack technical and legal information. This is something undesirable, since, in addition to drug labels being based on evidence, they must also be updated according to clinical information. ${ }^{21}$ Moreover, information contained on drug labels can influence clinical decision-making and, thus, compromise the quality of care based on clinical evidence. ${ }^{22}$

Thus, adequacy on the part of the pharmaceutical industries in the production of drug labels, and greater rigor in the approval and inspection carried out by ANVISA should take place. In addition, given the growing life expectancy and the fact that older people are considered a special population, a specific and explicit section on drug labels for older people would be mandatory, regardless of whether or not there are differences between this population and the others.

Although the present study is limited to the analysis of cardiovascular system drugs, it highlights the need to adapt drug labels to technical and legal information that contribute to the care process of older people, which is the fastest growing population in Brazil and worldwide, besides being the age group that uses the most drugs.

\section{CONCLUSION}

The study showed that only a small portion of drug labels that act on the cardiovascular system have explicit information in accordance with that contained in the CBMPII when it comes to older people. The lack of information and the existence of technical content that does not corroborate the scientific literature can cause serious consequences, such as increased errors in the prescription of drugs and risk of adverse events.

Therefore, explaining the possible adverse events and precautions regarding the use of drugs by older people on drug labels for professionals and users is essential, in order to contribute to the rational use and reduce the risks of use by this population.

\section{ACKNOWLEDGEMENT}

The authors would like to thank Universidade de Itaúna (UIT) and Universidade Federal de São João del-Rei (UFSJ), Campus Centro-Oeste Dona Lindu (CCO), for the support offered to research carried out.

\section{CONFLICT OF INTERESTS}

The authors declare there is no conflict of interests.

\section{FUNDING}

This study was carried out with the support of Minas Gerais State Research Support Foundation (Fundação de Amparo à Pesquisa do Estado de Minas Gerais - FAPEMIG) Coordination for the Improvement of Higher Education Personnel - Brazil (CAPES) - Financing Code 001.

\section{AUTHORS' CONTRIBUTION}

LOM: conceptualization, data curation, formal analysis, writing - original draft or review \& editing. RCV: conceptualization, data curation, formal analysis, writing — original draft or review \& editing. AOB: conceptualization, data curation, formal analysis, writing - original draft or review \& editing. ACNRP: writing - original draft or review \& editing. FMDC: conceptualization, data curation, formal analysis, writing - original draft or review \& editing. 


\section{REFERENCES}

1. Formiga LMF, Oliveira EAR, Borges EM, Santos KNC, Araújo AKS, Formiga RCF. Envelhecimento ativo: revisão integrativa. Rev Interd Ciên Saúde [Internet]. 2017 [Accessed in May 3, 2020];4(2):9-18. Available in: https://revistas.ufpi.br/index.php/rics/article/view/3854/3905

2. The Academy of Medical Sciences. Multimorbidity: a priority for global health research [Internet]. The Academy of Medical Sciences; 2018 [Accessed in May 3, 2020]. Available in: https://acmedsci.ac.uk/filedownload/82222577

3. Gbeasor-Komlanvi FA, Zida-Compaore WIC, Dare IH, Diallo A, Darre TP, Potchoo Y, et al. Drug Consumption Patterns and Polypharmacy among Community-Dwelling Elderly in Lomé (Togo) in 2017. Curr Gerontol Geriatr Res [Internet]. 2020 [Accessed in May 3, 2020];2020:4346035. Available in: https://www.hindawi.com/journals/cggr/2020/4346035/. https://doi.org/10.1155/2020/4346035

4. Ramos LR, Tavares NU, Bertoldi AD, Farias MR, Oliveira MA, Luiza VL, et al. Polypharmacy and Polymorbidity in Older Adults in Brazil: a public health challenge. Rev Saude Publica [Internet]. 2016 [Accessed in May 3, 2020];50(Supl. 2):9s. Available in: https://doi.org/10.1590/ S1518-8787.2016050006145

5. Baldoni AO, Chequer FMD, Ferraz ERA, Oliveira DP, Pereira LRL, Dorta DJ. Elderly and drugs: risks and necessity of rational use. Braz J Pharm Sci [Internet]. 2010 [Accessed in May 3, 2020];46(4):617-32. Available in: https://doi.org/10.1590/S1984-82502010000400003

6. 2019 American Geriatrics Society Beers Criteria ${ }^{\circledR}$ Update Expert Panel. American Geriatrics Society 2019 Updated AGS Beers Criteria ${ }^{\circledR}$ for Potentially Inappropriate Drug Use in Older Adults. J Am Geriatr Soc [Internet]. 2019 [Accessed in May 3, 2020];67(4):674-94. Available in: https://doi.org/10.1111/jgs.15767

7. Oliveira MG, Amorim WW, Oliveira CRB, Coqueiro HL, Gusmão LC, Passos LC. Consenso Brasileiro de Medicamentos Potencialmente Inapropriados para Idosos. Geriatr Gerontol Aging [Internet]. 2016 [Accessed in May 3, 2020];10(4):168-81. Available in: http://doi. org/10.5327/Z2447-211520161600054

8. Lopes LM, Figueiredo TP, Costa SC, Reis AMM. Uso de medicamentos potencialmente inapropriados pelos idosos em domicílio. Ciênc Saúde Colet. 2016;21(11):3429-38. http://dx.doi.org/10.1590/1413812320152111.14302015

9. Araújo LU, Santos DF, Bodevan EC, Cruz HL, Souza J, Silva-Barcellos NM. Patient safety in primary health care and polypharmacy: crosssectional survey among patients with chronic diseases. Rev Latino-Am Enfermagem [Internet]. 2019 [Accessed in May 3, 2020];27:e3217. Available in: https://doi.org/10.1590/1518-8345.3123.3217

10. Oliveira REM, Nascimento MMG, Reis FJ, Dias ERO, Pereira ML. Problemas farmacoterapêticos em idosos de uma unidade de atenção primária à saúde de Minas Gerais. Rev Eletr Farm [Internet]. 2016 [Accessed in May 3, 2020];13(4):201-11. Available in: https:// revistas.ufg.br/REF/article/view/40197. https://doi.org/10.5216/ref. v13i4.40197

11. European Parliament and of the Council. Regulation (EC) No. 726/2004 of the European Parliament and of the Council [Internet]. European Parliament and of the Council; 2004 [Accessed in May 3, 2020].
Available in: https://ec.europa.eu/health/sites/health/files/files/eudralex/ vol-1/reg_2004_726/reg_2004_726_en.pdf

12. Reis AMM, Alves CPB, Figueiredo TP, Barroso SCC, Nascimento MMG. Reação Adversa a Medicamentos como Fator Contribuinte para a Internação Hospitalar de Idosos. Rev Bras Farm Hosp Serv Saúde [Internet]. 2017 [Accessed in May 3, 20208(3):8-13. Available in: https://doi.org/10.30968/rbfhss.2017.083.002

13. McNeil JJ, Wolfe R, Woods RL, Tonkin AM, Donnan GA, Nelson MR, et al. Effect of Aspirin on Cardiovascular Events and Bleeding in the Healthy Elderly. N Engl J Med [Internet]. 2018 [Accessed in May 3, 2020];379(16):1509-18. Available in: https://doi.org/10.1056/ NEJMoa1805819

14. Saad M, Abdelaziz HK, Mehta JL. Aspirin for primary prevention in the elderly. Aging (Albany NY) [Internet]. 2019 [Accessed in May 3, 2020];11(17):6618-9. Available in: https://doi.org/10.18632/ aging.102255

15. Raber I, McCarthy CP, Vaduganathan H, Bhatt DL, Wood DA, Cleland JGF, et al. The rise and fall of aspirin in the primary prevention of cardiovascular disease. Lancet [Internet]. 2019 [Accessed in May 3, 2020];393(10186):2155-67. Available in: https://doi.org/10.1016/ S0140-6736(19)30541-0

16. Leelakanok N, Holcombe AL, Lund BC, Gu X, Schweizer ML. Association between polypharmacy and death: A systematic review and metaanalysis. J Am Pharm Assoc [Internet]. 2017 [Accessed in May 3, 2020];57(6):729-38.e10. Available in: https://doi.org/10.1016/j. japh.2017.06.002

17. Santos DJL, Feitosa ESM, Dalcin MF. A Importância da Bula Para o Usuário de Medicamentos. Braz J Surg Clin Res [Internet]. 2019 [Accessed in May 3, 2020];27(1):84-7. Available in: https://www. mastereditora.com.br/periodico/20190607_201024.pdf

18. Alshammari TM, Devadasu VR, Rathnam RP. Comparison of the safety information on drug labels in three developed countries: The USA, UK and Canada. Saudi Pharm J. 2017;25(8):1103-7. https://doi. org/10.1016/j.jsps.2017.07.006

19. Abedtash H, Duke JD. An Interactive User Interface for Drug Labeling to Improve Readability and Decision-Making. AMIA Annu Symp Proc. 2015;2015:278-86.

20. Brasil. Agência Nacional de Vigilância Sanitária. Resolução n 47, de 8 de setembro de 2009 [Internet]. Agência Nacional de Vigilância Sanitária; 2009 [Accessed in March 31, 2020]. Available in: http:// portal.anvisa.gov.br/documents/33836/2814380/RDC+47+09.pdf

21. Eteraf-Oskoueu T, Abdollahpour S, Najafi M, Zarea Gavgani V. Do drug package inserts meet the rules and regulations of Iran's Food and Drug Administration in terms of informing patients? Health Promot Perspect [Internet]. 2019 [Accessed in May 3, 2020];9(3):214-22. Available in: https://doi.org/10.15171/hpp.2019.30

22. Tefera YG, Gebresillassie BM, Ayele AA, Belay YB, Emiru YK. The characteristics of drug information inquiries in an Ethiopian university hospital: A two-year observational study. Sci Rep [Internet]. 2019 [Accessed in May 3, 2020];9:13835. Available in: https://doi.org/10.1038/ 541598-019-50204-1 